\title{
Analysis: An introduction to ethical concepts
}

\section{Equality}

\section{Alastair V Campbell New College, University of Edinburgh}

The notion of equality is a central concept in most codes of morality, particularly those concerned with the defence of civil rights. 'All human beings are born free and equal in dignity and rights', declares the first article of the United Nations' Universal Declaration of Human Rights (1948), and this claim finds clear historical antecedents in the documents which formed the bases of the English, American and French revolutions of the seventeenth and eighteenth centuries. But to what particular rights do such declarations refer? And by what criteria is the implementation of the equality they seek to be assessed ? Answers to these questions depend in part on an understanding of the social circumstances under which they were made, and in part on an analysis of the meaning of the term 'equal' when it is used to refer to the possession of rights.

\section{Political, legal and 'welfare' rights}

For the most part the stimulus for declarations about equality can be found in opposition to autocratic and unrepresentative systems of government and to arbitrary or repressive enforcement of laws which protect only certain groups within a society. Thus 'equality before the law', equal voting rights and equal opportunity to seek political office have been - and remain to be - cardinal issues in the quest for equality. In recent times, however, the concept of rights has been extended beyond the strictly political and legal to a sphere which may be loosely described as 'welfare rights'. This type of entitlement is formulated in the United Nations' Declaration in the following terms:

'Everyone has the right to a standard of living adequate for the health and wellbeing of himself and of his family, including food, clothing, housing and medical care and necessary social services, and the right to security in the event of unemployment, sickness, disability, widowhood, old age or other lack of livelihood in circumstances beyond his control' (Article 25(I)).

One may expect conceptual difficulties in any statement of rights, because they demand consider- able precision of definition in order to be of any practical relevance. Such difficulties are at their most acute when so comprehensive a claim to equal rights is put forward. In the case of political and legal rights the definitions can be largely negative in character - the specification of the conditions under which democratic government or due process of law are absent. But 'welfare rights' demand much more complex and contentious definitions, since they attempt to describe positive material entitlements. How, for example, is 'a standard of living adequate for health and wellbeing' to be assessed ? And what degree of redistribution of a society's material resources is called for in order to achieve such a standard? A discussion of these problems leads us to the concept of equity.

\section{Equality and equity}

From the writings of Plato and Aristotle onwards it has been observed that since people differ in numerous respects from one another justice cannot merely consist in treating them all equally. According to Aristotle, 'Injustice consists as much in treating unequals equally, as in treating equals unequally'. In other words, justice is ensured by meting out treatment to individuals in due proportion to their dissimilarities. However, such a view of justice allowed the philosophers of Athens to see no inequity in treating slaves, women - and indeed anyone not of pure Athenian stock-as selfevidently inferior to the citizens and therefore as undeserving of citizenship rights. Thus it is clearly essential that the relevant differences between people should be identified if the ideal of equity is not to be smothered by prejudice and arbitrary discrimination. D D Raphael (1970) has suggested the following formulation of a just discrimination between individuals: 'It is fair to discriminate in favour of the needy, or the meritorious, or the able, and it is unfair to discriminate between people who are equally needy, equally meritorious or equally able. The rule is to treat like cases alike and unlike cases differently'.

This formulation underlines the point that dissimilarity of treatment must have a moral justification if it is to be seen as part of a theory of justice. Inequality is prima facie wrong and can only be rendered acceptable morally if it can be shown to contribute to the goal of equitable treatment. 


\section{Grounds for discrimination}

It will be observed that Raphael uses as the criteria for fair discrimination three types of difference between individuals - need, merit and ability. These three criteria seem to echo some commonly held notions of 'fair play' in the distribution of social benefits. No doubt everyone would hope for equal opportunities to exercise his natural abilities, and to live in a society in which merit had its true reward and everyone's needs were fully met. Important as these criteria are, they are only the starting points for many philosophical and socio-political arguments.

In the first place all three criteria are highly ambiguous. 'Ability' carries with it numerous evaluative overtones: it may mean intellectual prowess, manual skill, artistic talent, technical ingenuity, etc, etc. How are relative values to be placed on these many different types of human activity? The situation is no better as regards 'merit'. Some may see obedience and loyalty as prime social virtues: others independence and initiative. Most ambiguous of all is the concept of 'need'. Apart from some obvious physiological preconditions for survival, it presents a minefield of social and psychological variables. Those living conditions regarded as the lowest tolerable in some societies must appear as undreamed of luxuries in others. As one set of 'basic minimum needs' is met by social changes a new set moves in to take its place. Thus 'need' must always be seen as a relative concept, with a high degree of built-in subjectivity and a seemingly limitless capacity for expansion.

Moreover, there is much room for argument about the relative importance of the three criteria in any calculation of equity. If merit is given the dominant role, then justice will best be served by providing adequate rewards to the most deserving citizens, at the expense, if necessary, of the less deserving. If the prime criterion is ability, then equality of opportunity must be stressed and maximum freedom given to the most able in a society to achieve personal success, socially and financially. Finally, if need is seen as the most important factor, then a redistribution of material benefits from the advantaged to the disadvantaged must be effected, on the grounds that the more able members of a society should use their abilities for the benefit of the society as a whole and not merely for personal gain.

\section{Equality, equity and health care}

Perhaps it is unnecessary to labour the point that different societies at the present time operate with very different conceptions of the relative importance of these three criteria, and that therefore debates about government interventions in health and welfare are to some extent the products of these differ- ent assumptions. Indeed current dilemmas about policy decisions in health care provide excellen examples of the problems we have been discussinge. Few could question the existence of major inequalis ties in health service provision both nationally and internationally. For example, the developed nations have a vastly disproportionate number of heal care personnel per head of population (Townsen I974), and within many of these developing nations the services which do exist are clustered in urbain centres and are most readily available only to $\vec{\beta}$ privileged few (Office of Health Economics, 1972) In developed nations, too, inequality of provision $\overrightarrow{\alpha s}$ a major problem, even if on a less dramatic scale Although the British National Health Service hơs achieved a reasonable uniformity of access to seir vices, it still retains considerable inequality in thefe standard of care available in different regions and $@$ different patient groups (Department of Health and Social Security, 1976).

The debate about health care priorities, in coup tries faced with such inequalities, resolves itsegff into a debate about the seriousness of the neeक् which present themselves. Recent British Govern ment health care policy has attempted a shifit toward better services for the elderly, the mentalky and physically handicapped and the residents of socially deprived areas. This shift has the inevitabte consequence of decreasing the survival chances off some patients in acute units (British Medictl fournal, 1976). Uncertainty about whether the right policy decision has been taken in this instange is a highly practical example of the problem of achieving equity in a society. The conceptual puzzless of the relationship between equality and equity hold a certain intellectual fascination for political philose phers: they also have their counterparts in the harsh realities of political decision making.

\section{References and suggestions for further reading}

British Medical fournal (1976). A policy of despain.

Editorial, I, 787.
Cooper, M H (1975). Rationing Health Care. London Croom Helm.

Department of Health and Social Security (1976). Priorities for Health and Personal Social Services is England. London, HMSO.

Maxwell, R (1974). Health Care: The Growing Dilemm New York, McKinsey \& Co.

Office of Health Economics (1972). Health Care 5 Developing Countries. London (OHE, I62 Regent Street, WIR 6DD).

Raphael, D D (1970). Problems of Political Philosophy. London, Macmillan.

Townsend, P (1974). Inequality and the health servige. Lancet, II79-II90.

Vlastos, G (1970). Justice and equality. In Human RigRts (A I Melden, editor). Belmont, California, Wa艝worth. 